\title{
Performance Management KPP Pratama Jakarta Tamansari Dua Based on Balanced Scorecard (BSC)
}

\author{
Hendi Aldrianto \\ Human Resource Management, State University of Jakarta \\ Rawamangun, Jakarta Timur, Indonesia \\ E-mail: hendi.aldrianto@gmail.com
}

Hady Efendy

Education Practice and Academic Consultant

E-mail: efendy_hady@yahoo.co.id

Received: Sept. 12, 2017 Accepted: Sept. 26, $2017 \quad$ Published: Oct. 12, 2017

doi:10.5296/csbm.v4i2.11842 URL: http://dx.doi.org/10.5296/csbm.v4i2.11842

\begin{abstract}
This research is conducted based on the success of achieving goals in companies that require effective management system, efficient and have the competitiveness in managing human resources owned. Through a good performance management system, the company can manage the performance of human resources owned so that it can work optimally and can achieve company goals. The effort of tax office (KPP) Pratama Jakarta Tamansari Dua in order to create effective and efficient performance management, which has competitiveness so that it can support productivity through applying a balanced scorecard (BSC) based performance management system. The purpose of this research is to explain the implementation of performance management system based on balanced scorecard in KPP Pratama Jakarta, and to analyze and explain the supporting factors and inhibiting the implementation of performance management system based on balanced scorecard in KPP Pratama Jakarta Tamansari Dua. The research method used in this research is descriptive qualitative. The results of this study indicate that the implementation of performance management system based on balanced scorecard in KPP Pratama Jakarta Tamansari Dua included in the management pattern of Human Resource Management Based Balanced Scorecard (HRMBSC).
\end{abstract}

Keywords: Balanced Scorecard, Performance Management System, Competence, Human Resources Management 


\section{Introduction}

One of the bureaucratic reform agenda that is the key to the success of a modern organization is the management of human resources that is good and directed by referring to the regulations in the field of employment that apply and always to reflects the ministry's values of integrity, professionalism, synergy, service and perfection. Reform in the field of Human Resources (HR) is a very important step for the Directorate General of Taxation (DJP), which supports the modern tax administration system through competency and performance based on human resources.

The DJP understands that human resources are the assets or strategic partners of an organization in achieving its objectives and the HR element in the DPJ has a strategic value as a determinant of the organization. The problem of human resources within an organization often encounters undesirable constraints, to map it the Director General of Taxes has issued a decision of the Director General of Taxation No. KEP-233 / PJ / 2011 on Blueprint of Human Resource Management Directorate General of Taxation Year 2011- 2018.

The Directorate General of Tax under the Ministry of Finance is a large organization with a total of 32,435 employees spread over 583 units throughout Indonesia. A phenomenal step has been taken by the leadership of the Ministry of Finance by conducting Bureaucratic Reform. Bureaucracy Reform in the Ministry of Finance has been started since 2006. Bureaucratic Reform is essentially an effort to make fundamental changes to the system of governance, especially in terms of institutional (organization), management (business process), and human resources (HR).

Many factors affect the work performance of these employees, some of which are emotional intelligence, compensation and commitment. One of the bureaucratic reform programs in the field of human resource management within the Ministry of Finance is the development of an assessment center. The purpose of the assessment center in the DPJ environment is to know the competencies of DPJ employees, in addition to emotional intelligence and motivation, the provision of compensation in accordance with the level of work and responsibility is essential so that employees feel appreciated.

Presidential Regulation no. 37 of 2015 on Employee Performance Enhancement in the Directorate General of Taxation environment published on March 19, 2015 is expected to make the employees within the Directorate General of Taxation can carry out their duties properly and full sense of responsibility and strive to achieve job performance that has been determined maximally.

Commitment has an important role especially on employee performance when working. The signing of Performance Contracts within the Directorate General of Taxes is one of the tools for employees to be responsible for their duties and responsibilities. The low commitment reflects the lack of responsibilities of employees in carrying out their duties. Questioning commitment is about questioning responsibility. Based on the above description, the author tries to formulate the problem proposed in this research is to know how the management of KPP Pratama Tamansari Dua employees performance. 
Type of Research the type of research used in this study is descriptive research with qualitative approach. Where the researcher describes how the implementation of performance management system based on balanced scorecard on KPP Pratama Tamansari Dua. According to Moleong (2007, p. 11) descriptive research is "research containing data citations to give a description of the presentation of research reports". The excerpts of the data presented are the result of interviews, field notes, personal documentation, notes or memos and other official documents. The origin of the data can be information about everything related to the implementation of a performance management system based on balanced scorecard. While the implementation of qualitative research according to Miles and Huberman (1992, p. 1) is research that comes from a broad description and solid ground, and contains an explanation of the processes that occur within the local scope. With qualitative research the data obtained can follow and understand the flow of events chronologically, assess causality in the sphere of the minds of local people, and obtain many useful explanations.

\section{Literature Review}

\subsection{Basic Concepts Systems in Organization}

The system is a collection of elements that are interrelated and mutually influence in conducting activities together to achieve a goal. Syamsi (2004, p. 16) also defines the system as "a set of activities consisting of subsystems that interact with each other and proceed to achieve certain goals”. From that sense, the subsystem is the procedures for performing a function. Between procedures that one with other procedures in one system are interrelated. While the method to implement a function is a component of the procedure. Everything is a process that relates to each other toward the goal.

\subsection{Basic Concepts of Performance Management}

Performance management by Susilo (2012, p. 6) is "activities related to planning, company, directing, and controlling the achievement of employee work and management efforts to continue to spur employee performance optimally". While performance management according to Dharma (2004, p. 16) is "a process to establish a common understanding of what should be achieved, and its approach to managing and developing human beings in a way that enables the goal to be achieved within a certain time frame”. Meanwhile, according to Bacal (1994) cited by Wibowo (2007, p. 8) view that "performance management as a continuous communication process in the partnership between employees with their immediate supervisor”. This communication process involves building clear expectations and understanding of the work to be done. Performance management is based on an assumption that employees know and understand what is expected of their company, and are included in the target setting that will be achieved then employees will show their performance to achieve those goals.

Various views on performance management above can be concluded that performance management is a managerial activity in managing company resources oriented to performance by conducting an open and sustainable communication process about shared vision and integrated strategic approach as a driving force to achieve corporate goals. 


\subsection{Performance Management System}

Performance management implementation should be viewed as a system that deals with other parts of the wider system. Bacal (2001, p. 48) states that "performance management must relate to strategic planning and direction of the company, budgeting process, employee development plans, and motivation improvement programs such as salary or wage rates, rewards and promotions. Maximum profit will be obtained if the company can implement the system as a whole not only one part only”. Meanwhile, Sahoo \& Jena (2012, p. 297) stated "A successful performance management system ensures that work performed by employees accomplishes the goals and mission of the organization and that employees have a clear understanding of what is expected of them". The statement means that the success of the performance management system can be ascertained by the success of the worker in achieving the goals and mission of the company. Workers have understood exactly what companies expect in terms of their performance.

\subsection{Balanced Scorecard}

The Balanced Scorecard is an approach to management strategies developed by Robert S. Kaplan (Harvard Business School) and David Norton in the early 1990s. Balanced scorecard comes from two words namely balanced and scorecards. Balanced means a balance between financial performance and nonfinancial, short-term performance and long-term performance, between internal performance and external performance. While the scorecard is a card used to record a person's performance score. The scorecard can also be used to plan the scores that a person is about to embody in the future. Robert S. Kaplan \& David P. Norton translated by Peter R. Yosi Pasla (2000, p. 22) define the balanced scorecard as follows: "Balanced scorecard translates missions and strategies into different objectives and measures, organized into four perspectives: finance, customers, internal business processes, and learning and growth. Another definition put forward by Supriyono (2000, p. 143) states that: "Balanced scorecard is one of the performance measurement tools that emphasizes the balance between strategic measures different from each other in an effort to achieve goal alignment so as to encourage employees to act in the best interests of the company”. While Mulyadi (2001, pp. 1-2) defines the balanced scorecard into two word terms, scorecard and balanced. The scorecard is the card used to record the performance score of a person, while balanced is intended to show that the performance of personnel is measured in a balanced way from the financial and non-financial, short-term and long-term, internal and external aspects.

\subsubsection{Advantages Balanced Scorecard}

The advantage of balanced scorecard approach according to Mulyadi (2001, pp. 18-24) in strategic planning system is able to produce strategic plan which has the following characteristics:

\section{1) Comprehensive}

The Balanced Scorecard extends the perspective covered in strategic planning, from previously limited to a financial perspective, extending across three perspectives: customers, internal business processes, and learning and growth. The strategic expansionary perspective 
to the non-financial perspective results in benefits: promising multiplied and long-term financial performance and enabling companies to enter complex business environments. Comprehensive strategic objectives are an appropriate response to entering a complex business environment.

\section{2) Coherent}

Coherent means the Balanced Scorecard requires personnel to establish causal relationships between the various strategic objectives generated in strategic planning. Any strategic objectives set out in a non-financial perspective must have a causal relationship to the financial objectives, either directly or indirectly. The strategic coherence generated in the strategic planning system motivates personnel to take responsibility for finding strategic initiatives that are useful for generating financial performance.

3) Balanced

The balance of strategic targets generated by strategic planning systems is essential to produce long-term financial performance. A more focused strategic objective to one perspective leads to another perspective neglected, this will affect the company's ability to generate long-term financial performance. Therefore, all existing balanced scorecard perspectives should be treated equally.

4) Measurable

The strategic objectives measurements generated by the strategic planning system promise the achievement of the strategic goals generated by the system. Balanced scorecard measures strategic goals that are difficult to measure. Non-financial perspective strategic objectives are not easy to measure, but in a balanced scorecard approach, the goals in those three non-financial perspectives are determined to be manageable in order to be realized.

\subsubsection{Weakness Balanced Scorecard}

Some weaknesses balanced scorecard according to Anthony \& Govindarajan (2005, p. 180) are:

1) Poor correlation between non-financial measures and outcome. There is no guarantee that future profitability will follow any non-financial goal achievement. This is a problem because of the inherent assumption that future profitability follows individual achievement.

2) Glued on financial results. Often managers are accustomed and trained with financial measures, but they also often get pressure from shareholders regarding their company's financial performance. Incentive programs can create additional pressure for senior managers because of the compensation provided based on financial performance.

3) Non-updated sizes. There are still many companies that do not have a formal mechanism to update the size of these measures in order to align with their strategic change.

4) Too many measurements made it can lead to less focused managers because trying to do many things at the same time. 


\section{Results and Discussion}

\subsection{Balanced Scorecard Implementation in KPP Pratama Jakarta Tamansari Dua}

Performance Management by Wibowo (2007) is a management style in managing performance-oriented resources that make the communication process open and sustainable by creating a common vision and strategic and integrated approach as a driving force to achieve organization goals.

Balanced scorecard (BSC), which is operated by KPP Pratama Jakarta Tamansari Dua, is a method developed by Kaplan and Norton to measure every activity undertaken by a company in order to realize the company's objectives. The BSC provides a framework for management to translate the organization's mission and strategy into objectives and measurements that can be seen from four perspectives. These four perspectives are meant to explain the appearance of an organization from the following four points of view:

1) Financial Perspective, the question: "to achieve financial success, which organization's financial performance should be shown to the owners of the organization?”

2) Customer Perspective, the question: "how does the organization look in the eyes of the customer?”

3) Internal Business Process Perspective, the question: "to satisfy the owners of the organization and its customers, which business process should be featured?”

4) Learning and Growth Perspective, the question: "how does the organization maintain its capabilities so that the organization continues to change better?"

Niven (2003) created the appropriate BSC framework model for use in non-profit/public organizations. The BSC framework model is different from the initial BSC framework model. The difference lies in the placement of the organization's mission at the top position in the BSC framework. This position shows that mission is the organization's primary goal with the customer's perspective as its driving force, since non-profit/public organizations are more focused on community service. According to Niven (2003), non-profit/public organizations using the BSC can modify the perspectives used in terms of numbers and types. This modification is done in accordance with the needs of the organization in reflecting its strategy better. Generally, non-profit/public organizations divide customer perspectives into 2 (two) sections, namely customer perspective and stakeholder perspective. This is due to the large number of customers owned by non-profit/public organizations as a customer-oriented organization, requiring more specific classification to make it easy to set strategic goals and the right size. In addition, according to Niven (2003), a financial perspective should still be used because the nature from a financial perspective is as a supporter (enabler) of customer service success.

Howard Rohm, a vice president of the Balanced Scorecard Institute formulated 9 (nine) successful steps of BSC development and implementation, written in an article in Perform Magazine, issue 2, volume 2. 6 (Six) first step is a successful step of BSC development, while three the next step is a successful step of BSC implementation. These steps are: 
1) Assessment. The first step in developing the BSC is to assess the core values of the organization. This can be done by formulating the vision, mission and values of the organization as the guidelines that underlie the organization to act in achieving the vision and mission that have been set.

2) Strategy. After formulating the vision, mission and value of the organization, the next step is to determine the strategy. Strategy is the way that the organization to achieve the vision and mission that has been set.

3) Objectives. The defined strategies are then detailed and focused into more specific strategic objectives.

4) Strategic Map. After establishing strategic goals, the organization creates a strategic map as a tool for communicating strategic goals to individuals within the organization. This strategic objective is then classified into every perspective used by the organization and illustrates the cause-effect relationship between each perspective.

5) Performance Measure. After the organization's strategic objectives are clearly defined through the strategy map, the next step is to measure the performance of the organization by determining the Key Performance Indicator/KPI (Primary Performance Indicator) of each strategic objective and setting the targets to be achieved by each KPI as a benchmark measure for the achievement of strategic goals.

6) Initiatives. Initiative is a work program implemented to support the achievement of targets of any defined strategic goals.

7) Automation. Step automation is the first step in implementing BSC. This step demonstrates the use of BSC software to collect data on individual performance achievements and manage individual performance reporting to make it more valid and effective.

8) Cascading. Process BSC should be applied at every level in the organization to maximize its benefits. The application of BSC at each level is done by reducing (cascading) the strategic target from the top level unit to the lower level unit. From this cascading process, each unit has a scorecard that is aligned with the level above. According to Luis \& Biromo (2010), there are 10 steps to down (cascading) BSC Company to division and individual level, namely:

a) Division Objectives. Analyze division's vision and mission.

b) Division Relevance. Identify the contribution and influence of the division on the company’s strategic map.

c) “Customer Division”. Identify the “customer” division.

d) Divisional Activities. Identify the core tasks (core processes) of the division.

e) Identify Customer Expectations. Tabulate customer output, customers, and expectations.

f) Lowering (cascading) SS Company to Division. Review Step 1, and identify the SS that should be downgraded to the Division, then specify the required additional SS division. 
g) Taking into account Local Issues. Look again at steps 2, 3, 4 and 5, and develop the Financial Perspectives Section for the Division, then the Internal Business Process Perspective and the Learning and Growth Perspective.

h) Consolidation and Logic Test. Prepare Division Strategy Map.

i) Choosing KPIs. Identify and define KPIs for each SS.

j) Determining Strategic Targets and Initiatives. Determining KPI targets and Strategic Initiatives for each SS.

9) Evaluation. The last stage in the implementation of BSC is to evaluate the achievement of performance that can be seen by comparing the targets with the realization of work.

\subsection{Application of Performance Management}

BSC Implementation on KPP Pratama Jakarta Tamansari Dua as a unit of Ministry of Finance-Three level is done by cascading process from Kanwil DJP as Unit level of Ministry of Finance-Two to KPP Pratama Jakarta Tamansari Dua as Unit level of Ministry of Finance-Three with the following steps:

1) Selecting Strategic Objectives (SS) on the DJP Regional Office Strategic Map. KPP Pratama Jakarta Tamansari Dua selects all strategic objectives contained in the Regional Office of DJP because SS owned by DJP Regional Office is relevant to the duties and functions of KPP Pratama Tamansari Dua.

2) Lowering SS and IKU. After selecting the SS on the DJP Regional Office strategic map, KPP Pratama Jakarta Tamansari Dua lowers the SS along with Key Performance Indicators (IKU) that measure SS achievement. IKU contained in the Regional Office of DJP is not entirely lowered, because there are 4 (four) IKU that are not relevant to the duties and functions of KPP Pratama Jakarta Tamansari Dua.

3) Adding SS and IKU. The addition of SS and IKU is done by KPP Pratama Jakarta Tamansari Dua because the duties and functions of the unit have not been fully accommodated by SS and IKU direct cascading and indirect cascading results. These added SS and IKUs are referred to as non-cascading SS and IKU. KPP Pratama Jakarta Tamansari Dua adds SS to the internal business process perspective, so KPP Pratama Jakarta Tamansari Dua must arrange the IKU to measure the achievement of the SS.

4) Encoding the SS, IKU and sub IKU. The coding of SS, IKU and sub-IKU to the Ministry of Finance-Three is based on Regulation of the Minister of Finance No. 151/PKM.01/2010 concerning Guidelines for Official Manuscripts of the Ministry of Finance.

5) Develop a Strategy Map. After establishing the SS and IKU and coding the SS and IKU, KPP Pratama Jakarta Tamansari Dua compiled a strategic map that maps SS as well as the SS code. Every SS present on the strategy map must have a cause-and-effect relationship with other SSs.

6) Setting Targets and Preparing Strategic Initiatives. After formulating a strategic map, KPP 


\section{Macrothink

Pratama Jakarta Tamansari Dua sets targets for each IKU and develops initiatives to achieve the target of the IKU. The Strategic Initiative in KPP Pratama Jakarta Tamansari Dua is called an action plan.

7) Cascading SS and IKU. After preparing the strategic map, KPP Pratama Jakarta Tamansari Dua can develop BSC to the level below, ie Ministry of Finance-Four level on Section Head and Sub-Division and Ministry of Finance-Five level on Account Representative (AR) and KPP Pratama Jakarta Tamansari Dua through process cascading.

8) Automation. All agencies of the Ministry of Finance, including KPP Pratama Jakarta Tamansari Dua automate the process of monitoring and evaluation of performance to be easier, efficient and real-time. Automation is done using e-performance applications. This application is web based with e-performance.depkeu.go.id which can be accessed through intranet network by all KPP Pratama Jakarta Tamansari Dua staff.

9) Evaluation of Activities. The evaluation was conducted quarterly by the Head of KPP Pratama Jakarta Tamansari Dua Office with its echelon IV officials and the organizational performance management partner as the person in charge.

After the strategic map of KPP Pratama Jakarta Tamansari Dua is established through the determined method, the next is to translate strategic targets in the strategic map into the Main Performance Indicator (IKU) for each Strategic Target (SS). IKU is a measuring tool for achieving SS. In the formulation of IKU should meet the characteristics of good performance indicators and sufficient for performance measurement using SMART-C principles, namely:

1) Specific. IKU must be able to express something unique/unique in assessing the performance of a work unit.

2) Measurable. The designed IKU must be clearly measurable, has a measurement unit, and it is clear how the measurement is.

3) Achievable. The selected IKU must be reachable by the person in charge or Unit in Charge.

4) Relevant. The chosen and defined IKU must be in accordance with the vision and mission, as well as the organization's strategic goals.

5) Time-bounded. The selected IKU must have a time limit for achievement.

6) Continuously Improve. The built IKU adapts to the development of organizational strategy.

Based on the above method, the main performance indicators (IKU) KPP Pratama Jakarta Tamansari Dua is divided into: 
Table 1. Details of key performance indicators

\begin{tabular}{|c|c|c|}
\hline Perspective & Strategic Target (SS) & Key Performance Indicators (IKU) \\
\hline Stakeholders & State’s Optimum State Revenue & $\begin{array}{l}\text { a. Percentage growth of tax revenue realization } \\
\text { (Non-Oil and Gas Income Tax) } \\
\text { b. Percentage of tax revenue realization } \\
\text { c. Percentage of tax exemption realization }\end{array}$ \\
\hline \multirow[t]{2}{*}{ Customers } & $\begin{array}{l}\text { High level of taxpayer satisfaction on } \\
\text { tax service }\end{array}$ & Number of taxpayers complain \\
\hline & High Taxpayer compliance rate & Percentage of SPT Annual submission \\
\hline \multirow{5}{*}{$\begin{array}{l}\text { Internal } \\
\text { Process }\end{array}$} & Improved quality of service & Average percentage of excellent service promises \\
\hline & $\begin{array}{l}\text { Increased } \quad \text { effectiveness } \\
\text { socialization and public relations }\end{array}$ & $\begin{array}{l}\text { a. Percentage of realization of socialization and } \\
\text { public relation } \\
\text { b. Percentage of number of WP conducted } \\
\text { socialization }\end{array}$ \\
\hline & $\begin{array}{l}\text { Increased exploration of potential } \\
\text { taxation }\end{array}$ & $\begin{array}{ll}\text { a. percentage of updating mapping realization } \\
\text { b. percentage of taxpayer profile creation } \\
\text { c. percentage of total issuance appeal for } \\
\text { rectification of Annual Tax Return } \\
\text { d. The percentage of fulfillment of the revision } \\
\text { of the Annual Income Tax Return on the basis } \\
\text { of the appeal. }\end{array}$ \\
\hline & $\begin{array}{l}\text { Optimization of } \quad \text { billing } \\
\text { implementation }\end{array}$ & $\begin{array}{l}\text { a. percentage of disbursement of tax receivables } \\
\text { b. the percentage of active billing } \\
\text { implementation }\end{array}$ \\
\hline & Increased effectiveness of inspection & $\begin{array}{l}\text { a. level of examination effectiveness } \\
\text { b. percentage of completion of inspection } \\
\text { completion } \\
\text { c. percentage of revenue realization of } \\
\text { inspection results }\end{array}$ \\
\hline \multirow{3}{*}{$\begin{array}{l}\text { Learning and } \\
\text { Growth }\end{array}$} & $\begin{array}{l}\text { Highly competent human resource } \\
\text { formation }\end{array}$ & $\begin{array}{l}\text { a. IHT hour rate of working hours } \\
\text { b. percentage of implementation of coaching } \\
\text { meetings }\end{array}$ \\
\hline & Adaptive organization arrangement & $\begin{array}{l}\text { a. percentage of risk mitigation completed } \\
\text { b. the percentage policy recommendation of } \\
\text { follow up supervision results } \\
\text { c. the percentage of timely report submission }\end{array}$ \\
\hline & Implementation of optimal budget & $\begin{array}{l}\text { Percentage of DIPA absorption of non-personnel } \\
\text { expenditure }\end{array}$ \\
\hline
\end{tabular}

\subsection{Discussion}

KPP Pratama Jakarta Tamansari Dua uses performance management using BSC as a tool to manage, measure and assess the performance of organizations and individuals. The use of BSC is the right decision because BSC is also popular in the corporate or private world in performance measurement, BSC has also been adopted for public organizations or government agencies.

BSC was only used around 2010 so that socialization and education about BSC continuously conducted by KPP Pratama Tamansari Dua. Organizational Performance Manager is performed by Data Processing and Information (PDI) section and Individual or Employee Performance Manager implemented by General sub-section (General Sub-Division). Socialization and education have an impact on the use of BSC application through 
e-performance although there are still employees do not understand how to fill the IKU in the application then the PDI section or public sub section will soon help.

Achievement of performance as measured by BSC is still integrated with reward only. Giving rewards does give a positive thing on improving the performance of KPP Pratama Jakarta Tamansari Dua but it should be reward is also accompanied by the provision of punishment. Thus, KPP Pratama Jakarta Tamansari Dua can minimize the decline in organizational performance that can happen at any time. Reward received by the organization in the form of incentives that are evenly distributed to all employees within the organization. Thus, both employees who achieve IKU targets and who have not reached IKU targets get the same amount of incentives. Incentives given to an equal amount can have a negative impact that may someday occur: employee demotivation due to incentives being generalized.

The critical point in using BSC is how to lower the BSC of DJP agencies to the level of KPP Primary and individual, which according to Luis \& Biromo (2010) there are 10 cascading steps. The ten steps have been implemented by the Directorate General of Taxes as the first echelon unit, then lowered to the DJP Regional Office of West Jakarta as the 2nd echelon unit, then lowered to KPP Jakarta Tamansari Dua as the 3rd echelon unit and also the duty bearer of the Directorate General of Taxes.

The four perspectives of the BSC are the perspectives of stakeholders, customers, internal processes and learning and growth as well as have been operational translated into strategic targets. The stakeholders' perspective is operationalized to be the optimal State tax revenue, in accordance with the DJP's mission or principal objectives (duties) as the agency that collects the State revenue from the tax sector used for development financing. The customer perspective is operationalized in 2 (two) strategic objectives: Increasing the satisfaction and compliance of Taxpayer This reflects that the taxpayer as DJP customer is very important to be fulfilled all the needs related to the tax service so that if measured by Customer Satisfaction Index (CSI) will show the high satisfaction level of WP. With high CSI, it is expected that WP's compliance with its tax obligations also increases. Then the third perspective concerning internal business processes translated into 4 (four) strategic objectives is appropriate because the strategic objectives are in line with the main business processes of DJP and KPP Jakarta Tamansari Dua.

\section{Conclusions and Recommendations}

Some things that can be inferred from the above description are as follows:

1) KPP Pratama Jakarta Tamansari Dua uses performance management with Balanced Scorecards.

2) Performance Management System based on Balanced Scorecards using Cascading 10 stages starting from Ministry of Finance level, down to Directorate General of Taxes, down to Regional Office of DJP West Jakarta, and finally to Tax Office Pratama Jakarta Tamansari Dua. 


\section{Macrothink}

Case Studies in Business and Management

ISSN 2333-3324

2017, Vol. 4, No. 2

3) Balanced scorecard managed at KPP level by section Data processing and Information for organizational performance and by general sub section for employee performance.

4) The results of the performance management assessment Balanced Scorecards are used as a basis for rewarding employees.

Some things that can be used as a recommendation for the implementation of subsequent change management at the Tax Office, including:

1) Need more intensive socialization and education about Balanced Scorecards to employees, especially for the use of e-performance.depkeu.go.id.

2) Main Performance Indicator (IKU) can still be developed further according to the dynamics of KPP environment, in KPP pratama Jakarta Tamansari Dua more directed to the strengthening of the organization.

3) Four perspectives applied in strategic targets can still be developed especially Learning and Growth need to be developed IKU for higher education more emphasized.

4) Use of Balanced Scorecards results for employee rewards to be developed for rewards at the office level.

\section{References}

Anthony, G. (2001). Management Control System (10th edition). New York: McGraw-Hill Companies, Inc.

Bacal, R. (2001). Performance Management. Jakarta: Gramedia Pustaka Utama.

Dharma, S. (2004). Manajemen Kinerja, Falsafah, Teori dan Penerapannya. Jakarta: Direktorat Jendral Pendidikan Tinggi Departemen Pendidikan Nasional.

Kaplan, R. S., \& Norton, D. P. (2000). Balanced Scorecard (p. 4). Terjemahan Peter. R. Yosi Pasla. Jakarta: Erlangga.

Luis, S. \& Prima, A. B. (2010). Step by Step in Cascading Balanced Scorecard to Functional Scorecards. Jakarta: PT Gramedia Pustaka Utama.

Miles, M. B., \& Huberman, A. M. (1992). Analisis Data Kualitatif. Jakarta: Penerbit Universitas Indonesia (UI-Press).

Moleong, L. J. (2007). Metodologi Penelitian Kualitatif ed. revisi. Bandung: Remaja Rosdakarya.

Mulyadi. (1998). Akuntansi Manajemen: Konsep, Manfaat dan Rekayasa. Edisi 3. Yogyakarta: STIE YKPN.

Sahoo, C. K., \& Jena, S. (2012). Organizational Performance Management System: Exploring the Manufacturing Sectors. Industrial and Comercial Training, 44(5), 296-302. https://doi.org/10.1108/00197851211245059

Susilo, H. (2012). Manajemen Kinerja dan Kompensasi. Malang: UB Distance Learning. 
Syamsi, I. (2004). Efisiensi, Sistem, dan Prosedur Kerja. Jakarta: Bumi Aksara.

Wibowo. (2011). Manajemen Kinerja. Jakarta: Raja Grafindo Persada.

Wibowo. (2016). Manajemen Kinerja Edisi Kelima. Jakarta: PT RajaGrafindo Persada.

Zulfansyah, M. Y., \& Amri. (2016). Pengaruh Kecerdasan Emosional, Kompensasi dan Komitmen Terhadap Kinerja Karyawan Serta Implikasinya Terhadap Kinerja Kantor Pelayanab Pajak Pratama Majalaya. Jurnal Manajemen Pascasarjana Universitas Syiah Kuala, 5(1), Februari.

\section{Copyright Disclaimer}

Copyright for this article is retained by the author(s), with first publication rights granted to the journal.

This is an open-access article distributed under the terms and conditions of the Creative Commons Attribution license (http://creativecommons.org/licenses/by/3.0/). 